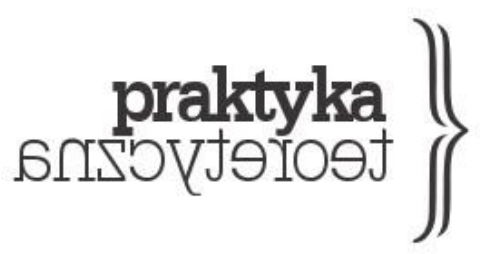

ISSN 2081-8130

DOI: $10.14746 /$ prt.2018.2.4 www.praktykateoretyczna.pl

\title{
PLASTYCZNOŚĆ I REWOLUCJA. DE TOCQUEVILLE, MALABOU, LUKÁCS
}

\author{
MACIEJ ADAM SOSNOWSKI
}

\begin{abstract}
Abstrakt: Dialektyczna koncepcja rewolucyjności podkreśla jej podwójny charakter. Zarówno w wersji konserwatywnej (de Tocqueville), jak i socjalistycznej (Lukács) rewolucja jest więc świadectwem ciąłłości historycznej i zarazem jej gwałtownym zerwaniem. Celem niniejszego eseju jest uchwycenie tego dwuznacznego fenomenu przy wykorzystaniu pojęcia plastyczności Catharine Malabou. Plastyczność, jako współczesna, postdekonstrukcyjna formuła Heglowskiego Aufhebung, jest pasywno-aktywnym formowaniem, niszczeniem formy i jej zachowywaniem. Jej istota pokrywa się więc z istotą myślenia o rewolucji, zarówno de Tocqueville’a, jak i Lukácsa. Taka dwuznaczność rewolucji może być jednak odczytywana jako wyraz pewnej porażki idei rewolucji jako takiej. Jej uwikłanie w przeszłość skazuje ja na bezproduktywny oportunizm, jej wychylenie w przyszłość - na pusty mesjanizm, a poszukiwanie idealnego zapośredniczenia między tymi skrajnościami zdaje się nie mieć końca. Jeśli współczesność jest trapiona przez to fiasko, to triumfuje w niej przynajmniej jeden aspekt idei rewolucji - pewien sposób myślenia o niej, spekulatywność czy też dialektyka jako taka.
\end{abstract}

Słowa kluczowe: plastyczność, rewolucja, dialektyka, czasowość, Hegel, Malabou. 


\section{1. de Tocqueville}

Wolteriański atak na teodyceę dla konserwatywnego Josepha de Maistre'a miał istotne przełożenie na gwałtowność późniejszej, rewolucyjnej zawieruchy. Podważenie sensowności cierpienia na świecie było równoznaczne z podważeniem boskiego planu, w którym kara I pokuta wymierzane są sprawiedliwie, choć niejawnie dla jednostek. A skoro plan taki zdaje się w ramach oświeceniowej ideologii jedynie religiancką projekcją, to nic nie stoi na przeszkodzie, aby co bardziej zapalczywe grupy wzięły na siebie ciężar bycia sędzią i katem. Jak czytamy w Wieczorach petersburskich:

Czy może Wolter otrzymał boską wagę, by odważyć zbrodnie królów i zwykłych jednostek i akuratnie oznaczać czas kary? A cóż powiedziałby ów zuchwalec, gdyby [...] mógł naraz zobaczyć w nieodległej przyszłości Komitet ocalenia publicznego, Trybunał rewolucyjny i długie karty „Monitora”, ociekające szkarłatem ludzkiej krwi? (de Maistre 2011, 151)

Skoro nie ma transcendentnej instancji sędziego, zaczyna się krwawy terror, dyrygowany przez ludzi. Ale u de Maistre’a krytyka Woltera nie opiera się na podkreślaniu niesprawiedliwości terroru, o który pośrednio się go obwinia. Nie chodzi o konsekwencje postawy Woltera, ale o jej przesłankę. Sprawa jest więc znacznie prostsza.

To, czego nie rozumie oświecenie ze swoją krytyką religii, to wedle prawdziwego ultramontanisty fakt, że religia jest niezniszczalna i prawdziwa. Zatem zupełnie przypadkowe i niezrozumiałe wydarzenia - jak trzęsienie ziemi pochłaniające tysiące ofiar czy krwawe przewroty społeczne - nie potrafią zachwiać szczerą wiarą z tego prostego powodu, że wcale nie sa przypadkowe. Tylko jednostkowa ignorancja nie pozwala dostrzec w nich elementu wielkiego planu, siejąc zamęt w głowach słabszych i bardziej podatnych na sugestię. Linia argumentacyjna de Maistre'a jest tutaj znamienna:

Jeśli bowiem postanowione jest, że pewna liczba dzieci musi zginąć, nie wiem, jakie ma dla nich znaczenie, czy zginą w taki czy inny sposób. Człowiek umiera tak samo, czy to od sztyletu przeszywającego serce, czy też dlatego, że zebrało mu się trochę krwi w mózgu - w pierwszym przypadku jednak mówimy, że skończył gwałtowną śmiercią. Dla Boga nie ma jednak żadnej gwałtownej śmierci (de Maistre 2011, 150).

Dla Boga nie istnieje nic gwałtownego - nie ma w dziejach zbawienia wydarzeń nagłych czy nieprzewidzianych. Każde cierpienie jest konieczne, choćby nie wiadomo jak nagłe i niespodziewane nam się zdawało, a świat na nie zasługuje, jako że jest siedliskiem grzechu. Wszystko toczy się jednostajnym, z góry określonym rytmem, który wyklucza przypadek. 
Przypadkowość jako taka jest jedynie zjawiskiem złudzenia perspektywicznego. De Maistre, będąc tutaj doprawdy konsekwentnym, może nawet wbrew swoim ewentualnym resentymentom, stawia sprawę jasno - zarówno katastrofy naturalne, jak i katastrofy społeczne nie są czymś, co wykraczałoby poza boskie zrządzenia (por. np. Barut 2008). Zatem i rewolucja, choć może jawić się, szczególnie konserwatyście, jako bezsensowna erupcja niepohamowanej i niczemu niesłużącej przemocy, jest przejawem ciąłości dziejów. Ciagłości, której nic nigdy nie może zaburzyć (nawet tak radykalne wtargnięcie inności w bieg świata jak wydarzenie inkarnacji Boga).

Wizja historii, w której nic się nie wydarza, w tym sensie, że wszystko jest konsekwencją odwiecznego planu, jest oczywiście jedną ze strategii obronnych zgorzkniałego konserwatyzmu, który stara się jakoś załagodzić traumę i porewolucyjny szok, próbując na swój sposób pojąć, czym były wydarzenia 1789 roku. Ale i rozsądny konserwatyzm skłania się ku takiej interpretacji „wydarzeniowości”, choć - i na tym zasadza się wspomniany wyżej rozsądek - sprawa wygląda tutaj dużo bardziej dwuznacznie.

Przyglądając się z narastająca obawa, jak władza Napoleona III niechybnie zmierza w stronę dyktatury, Alexis de Tocqueville po okresie krótkiego ministrowania w rządzie Odilona Barrota wycofuje się z życia publicznego Francji. Wtedy właśnie zaczyna pisać swoje Wspomnienia, będące zarówno pasjonująca lektura historyczno-biograficzna, jak i czymś w rodzaju wprowadzenia do wielkiego, klasycznego już dzieła Dawny ustrój $i$ rewolucja. Ale to właśnie we Wspomnieniach pomiędzy opisami wydarzeń i anegdotami o głównych bohaterach rewolucji, tym razem 1848 roku, de Tocqueville snuje swoje rozważania, rozwinięte później w książce o ancien régimie. Czytamy więc:

Ze swej strony żywię odrazę do owych absolutnych systemów, które uzależniaja wszystkie historyczne wydarzenia od wielkich przyczyn sprawczych powiązanych między sobą w fatalistyczne łańcuchy, które [...] wykluczają człowieka z historii ludzkiego rodzaju. Znajduję, że są ciasne mimo ich rzekomej wielkości i fałszywe pod pozorami matematycznych prawd. Choć nie spodoba się to twórcom, którzy wymyślili te wzniosłe teorie [...], jestem przekonany, że wielu ważnych faktów historycznych nie da się wytłumaczyć inaczej jak przypadkowymi okolicznościami i że $[\ldots]$ przypadek [...] liczy się bardzo w tym, co oglądamy w teatrze świata. Lecz równie mocno jestem przekonany, że przypadek nie czyni niczego, co uprzednio nie byłoby przygotowane (de Tocqueville 1987, 74).

Inaczej niż w wizji de Maistre’a tutaj doceniona zostaje więc rola przypadku w kształtowaniu dziejów. Ale jednocześnie wciąż kładzie się tu nacisk na pewną strukturalną ciagłość, która, zdawałoby się, przypadek eliminuje. Jak rozumieć ten podwójny status gwałtownych 
wydarzeń historycznych, to wpisane w rewolucję bycie zarówno momentem zerwania, jak I potwierdzeniem ciagłości?

Warto jednak już teraz poczynić pewną uwagę metodologiczną. Otóż w tych skromnych analizach nie rościmy sobie pretensji do rozstrzygnięcia niezmiernie skomplikowanego problemu przyczyn stojących za wybuchem rewolucji francuskiej, Wiosny Ludów, rewolucji bolszewickiej etc. Nie chcemy również decydować, czy np. propozycje de Tocqueville'a są zasadne i czy trafnie rozpoznawał on genezę wydarzeń historycznych. Interesuje nas bowiem coś innego - nie historyczna empiria i nie socjologiczna rzetelność, ale intuicje filozoficzne stojące za analizowanymi tutaj fragmentami. Chodzić nam będzie o to, jaką idea „rewolucji”, „zmiany” bądź „wydarzenia” w ogóle posługują się przywoływani myśliciele, jakie struktury pojęciowe są przez nich angażowane, kiedy piszą o „rewolucji”, a nie o to, czy z punktu widzenia nauki mają oni rację, czy też fatalnie się omylili ${ }^{1}$.

Wracając więc do przerwanego wcześniej wątku: teza de Tocqueville’a z Dawnego ustroju $i$ rewolucji jest powszechnie znana (por. np. Kuź 2016). Zanim jednak do niej przejdziemy, warto przypomnieć, że w samym tym dziele autor raz po raz daje wyraz owej gwałtownej przypadkowości rewolucji, która była wydarzeniem dla większości zupełnie niespodziewanym. Niespodziewanym tym bardziej, że w zasadzie niemożliwym do teoretycznego ujęcia:

\begin{abstract}
Ale nam, którzy patrzymy na szczątki tylu rewolucji, najdziwniejsze wydać się musi to, że samo pojęcie gwałtownej rewolucji nie istniało w umysłach naszych ojców. Nie dyskutowano o niej, nikt jej sobie nie wyobrażał. [...] Ci, którzy jutro staną się jej ofiarami, ani się tego domyślają, sądza, że całkowite i nagłe przekształcenie społeczeństwa tak złożonego i starego może się dokonać bez wstrząsu, za pomoca samego rozumu i dzięki jego skutecznym zabiegom. Nieszczęśni! (de Tocqueville $2005,184)$
\end{abstract}

W świetle tego cytatu można wręcz sądzić, że największą zmianą, jaką wprowadziła rewolucja, było to, że od jej wybuchu coś takiego jak rewolucja w ogóle stało się do pomyślenia. Rewolucja przede wszystkim zrewolucjonizowała myślenie o niej samej. Wywróciła do góry nogami stary, konserwatywny, metafizyczny ład, w którym porządek teodycei regulował bieg zdarzeń, z których z kolei żadne nie nosiło piętna radykalnej przemiany. W tym sensie rewolucja była niemożliwa tak długo, jak długa się nie wydarzyła, samo zaś jej zaistnienie wytworzyło pojęcie odnoszące się do niej, nowe i niewywodliwe z dotychczasowych siatek pojęciowych. Rewolucja tak pomyślana jest epistemicznym cięciem, realizacją pewnej

1 Np. wielokrotnie podkreślano, że de Tocqueville w ogóle nie bierze pod uwagę kryzysu gospodarczego pod koniec lat osiemdziesiątych osiemnastego wieku (np. Hobsbawm 2013, 96) jako głównego czynnika sprawczego przewrotu. 
rzeczywistej odmienności - odmienności zarówno formalno-genetycznej, bowiem zaistniała ona właśnie na drodze rewolucji, jak i treściowej, ponieważ w ujęciu filozoficznym jej treścia jest ona sama jako zupełnie nowy przedmiot refleksji. Co więcej, nie pochodząc w żaden sposób ze starego ładu, rewolucja sama się stwarza, jakby sama w polu teoretycznym była własną przyczyną - póki się nie wydarzy, nie sposób jej pojać, ale nie może się wydarzyć jako ona sama, jako rewolucja, jeśli nie zaistnieje jej teoretyczno-filozoficzne ujęcie. Innymi słowy, rewolucja rozpatrywana od strony filozoficznej ma charakter paradoksalnej causa sui, która kiedyś nie istniała.

Oczywiście ten typ spekulacji obcy jest pismom de Tocqueville’a. Jakkolwiek podkreśla on „wydarzeniowość” roku 1789, to jednak większy nacisk kładzie na drugi aspekt rewolucyjności, na jej uwikłanie w historyczną ciagłość (co wydaje się zrozumiałe o tyle, że gwałtowność i nagłość rewolucji nie była czymś, do czego ludzi w dziewiętnastym wieku trzeba było przekonywać). We fragmencie, w którym autor streszcza główną ideę dzieła, czytamy więc:

\begin{abstract}
Choć tak radykalna, Rewolucja była wszakże znacznie mniej nowatorska, niż się na ogół przypuszcza [...]. Prawda jest, że całkowicie zniszczyła bądź niszczy (bo jeszcze trwa) wszystko, co w dawnym społeczeństwie pochodziło z instytucji arystokratycznych i feudalnych, wszystko, co się z nimi jakoś wiązało, wszystko, co w jakimkolwiek, choćby najsłabszym stopniu nosiło ich piętno. [...] Natomiast w minimalnym stopniu była wydarzeniem przypadkowym. Choć zaskoczyła świat, była jedynie dopełnieniem długiej pracy, nagłym i gwałtownym zakończeniem dzieła, przy którym trudziło się dziesięć ludzkich pokoleń (de Tocqueville 2005, 56).
\end{abstract}

Dalej de Tocqueville analizuje strukturę administracji państwowej schyłkowej fazy monarchii absolutnej, podkreślając obecną w niej tendencję do centralizacji i racjonalizacji stosunków społecznych. Intendentura, wynalazek ancien régime’u, zagwarantowała wzrost kompetencji urzędników państwowych, którzy stawali się przedłużeniem władzy centralnej, i niwelowała znaczenie zwierzchnictwa opartego na starych relacjach feudalnych - „Zostawiono im [przedstawicielom monarchii feudalnej - przyp. MAS] jeszcze zaszczyty, ale nie maja już żadnej władzy. Cała władza jest w rękach intendenta" (de Tocqueville 2005, 74). Ta tendencja do przenikania całego społeczeństwa przez zracjonalizowany system władzy centralnej charakterystyczna jest właśnie dla dążeń rewolucyjnych - „Rewolucja nie obaliła centralizacji, ponieważ ta była jej poczatkiem i oznaką" (de Tocqueville 2005, 99). W tym sensie rewolucja nie burzy starego ładu, a jedynie oczyszcza go z niewydolnych feudalnych resztek w postaci praw i przywilejów rodowych arystokracji. Jednocześnie wraz ze spadkiem znaczenia szlachty postępuje ujednolicenie społeczeństwa, któremu tym bardziej przeszkadzają te prawne relikty przeszłości. Głównym dziełem rewolucji jest więc zniszczenie pustych form przeszłości, 
aby forma nowa - scentralizowana władza rządu - mogła już działać bez zakłóceń i obejmować całość społeczeństwa.

Tak rozumiana rewolucja rzeczywiście jest świadectwem historycznej ciagłości. Pewne procesy, które de Tocqueville śledzi w społeczeństwie francuskim od lat czterdziestych osiemnastego wieku (podkreślając przede wszystkim wielką reformę administracji z 1787 roku), zarówno charakteryzowały stary ustrój, jak i były wyznacznikiem rzekomej „nowości” rewolucji. Nie ma więc tu miejsca na cięcie i zerwanie, rewolucja bowiem jedynie, choć w spektakularny sposób, realizowała mechanikę działania dotychczasowego systemu społecznego. Jej gwałtowność była wynikiem frustracji mieszczaństwa związanej z wyróżnioną, choć już zupełnie nieuzasadnioną rolą arystokracji (Por. de Tocqueville 2005, 245.), ale to nie zniszczenie było treścią i celem rewolucji, a zachowanie i obrona dotychczasowych osiagnięć ancien régime’u.

W Dawnym ustroju $i$ rewolucji mamy więc do czynienia $z$ pewnym podwojeniem myślenia o rewolucji, zupełnie nieobecnym u de Maistre’a (który jawi się niczym owi nieszczęśni, którzy nie dysponują pojęciem „rewolucji”). Rewolucja zarówno urzeczywistnia treść starego systemu, jak i niszczy jego formalne ograniczenia, zarazem konserwuje jego istotę i pozbywa się bezużytecznych akcydensów. W pewnym sensie dopiero wydarzenie rewolucji umożliwia obecnym od dawna tendencjom starego ustroju urzeczywistnić swój pełny potencjał.

Rewolucja jest więc nieodrodnym dziełem starego ustroju, wynikającym z jego długiej i mozolnej pracy, jak i, mimo wszystko, zrywem, który wstrzymuje dotychczasowy bieg historii. Jest czymś nie do pojęcia, a jednocześnie wynika z analizy zastanych stosunków. Jest zerwaniem i ciagłością. Jest do pomyślenia zarówno jako czas, w którym tak naprawdę nic nowego się nie wydarza, jak i jako czas realizacji tego, co radykalnie nowe i inne. Jest okresem końca i początku, a zarazem jednym z wielu wydarzeń w jednolitym nurcie historii. De Tocqueville jest wybitnym teoretykiem tak rozumianej rewolucji, która tworzy i niszczy w tym samym ruchu swego dziania się.

Chcielibyśmy zaryzykować tutaj tezę, że taka „filozofia rewolucji” ma charakter plastyczny. Plastyczny w rozumieniu, jakie stosuje Catherine Malabou. Jak jednak rozumieć tę plastyczność i w jaki sposób pojęcie plastyczności może w ogóle kształtować pewien paradygmat rozumienia rewolucyjności? 


\title{
2. Malabou
}

Malabou swoją koncepcję plastyczności rozwija w oparciu o dialektykę Hegla. To u niego, w Przedmowie do Fenomenologii ducha, znajduje się fragment dotyczący specyfiki „zdania spekulatywnego", gdzie czytamy:

\begin{abstract}
Należałoby unikać trudności, którą stanowi pomieszanie spekulatywnego i rezonującego sposobu myślenia, zachodzące wówczas, gdy to, co się mówi o podmiocie, raz ma znaczenie jego pojęcia, innym zaś razem znaczenie jego orzecznika albo akcydensu. Jeden sposób przeszkadza tu drugiemu i dopiero wykład filozoficzny rygorystycznie wykluczający zwykłe stosunki między częściami zdania mógłby osiagnąć plastyczność (Hegel 2002, 52).
\end{abstract}

Plastyczność to cecha rzetelnego filozofowania dialektycznego, w którym nie ma miejsca na nieprzekraczalne dychotomie pomiędzy podmiotem a orzecznikiem, nie ma też miejsca na dychotomie pomiędzy treścią zdania (zdania spekulatywnego) a jego formą. Prawdziwa dialektyka zawsze ma na względzie plastyczność - w pewnym sensie plastyczność to inna nazwa (zdekonstruowanej) dialektyki (por. np. Martinon 2007, 27-68), ruchu niszczenia i zachowywania, negowania i afirmacji.

Tak rozumiana plastyczność jest, jak wielokrotnie powtarza Malabou, zarówno pasywnościa podmiotu, który jest w stanie przyjąć każdą formę, jak i aktywnością owego podmiotu, który formy te sam generuje ${ }^{2}$. Innymi słowy, to rodzaj dynamicznej syntezy, kreatywnego zapośredniczenia pomiędzy stwarzanymi uprzednio różnicami i zerwaniami. Jak pisze Malabou pod koniec The Future of Hegel: „Plastyczność to nazwa pierwotnej jedności aktywności oraz bycia poddanym działaniu, spontaniczności i receptywności. Jako medium różnicowania opozycji plastyczność skupia skrajności we wzajemnym oddziaływaniu [...]” (Malabou 2005, 186).

Już to ogólne określenie plastyczności pozwalałoby w sposób równie ogólny na dialektyczną analizę wcześniej nakreślonego rozumienia rewolucyjności. Rewolucja byłaby więc rodzajem pasywnej aktywności, która znosząc stare formy i tworząc coś nowego, jednocześnie zachowuje status quo, ale na innym poziomie, w innym kontekście teoretycznym i historycznym. Rewolucja byłaby więc plastyczna o tyle, o ile jej możliwe do pomyślenia struktury byłyby tożsame ze spekulatywnym Aufhebung. Wydaje się jednak, że konkretyzacja, jakiej plastyczność poddaje Malabou, jest tutaj o wiele ciekawsza. W tym samym fragmencie

2 Ta dwuznaczność plastyczności odróżnia ją od elastyczności (materiał elastyczny, poddany zmianie, powraca do swej pierwotnej formy i sama aktywność formowania okazuje się pozorna) i giętkości (materiał giętki poddaje się zmianie bez oporu, jest całkowicie pasywny). 
czytamy bowiem dalej: „[...] pierwotna operacja przyjmowania i dawania formy nie jest sztywną i stałą struktura, ale instancją zdolną do ewoluowania, co znaczy, że może dawać sobie samej nowe formy. Czasowe zróżnicowanie plastyczności umożliwia historyczny przebieg podmiotu-substancji” (Malabou 2005, 186)

To właśnie powiązanie plastyczności z czasowo rozumianym zniesieniem stanowi o oryginalności koncepcji Malabou i pozwala rzucić nowe światło na sposób, w jaki nowożytna, postdialektyczna filozofia posługuje się pojęciem „zmiany”.

Kiedy Malabou z perspektywy kilku lat stara się uchwycić istotę swojej książki o Heglu, przywołuje właśnie kwestię spekulatywnej temporalności - czy raczej dwóch, a nawet trzech czasowości związanych w dialektycznym wę́le - jako clou swojego dzieła. W Plasticity at the Dusk of Writing czytamy więc:

Według Hegla istnieje pierwsza negacja, inicjujące „nie”, którego istota jest grecka i które zakorzenia rzecz w samej sobie i determinuje jej stałość $[\ldots]$ - konstytutywna praca obecności. Dalej istnieje inne „nie” pochodzenia chrześcijańskiego, które, dla kontrastu, jest wyjściem z siebie, eksterioryzacją (Entäußerung) i alienacją tej samej rzeczy. [...] Prawdziwie spekulatywna czasowość, w której obecność wraca do siebie z tego wyobcowania, spaja ze soba to czasowe podwojenie [...]. Dlatego praca osadzania tożsamości jest zawsze zarówno żałobą obecności (Malabou 2010, 18).

Zanim przejdziemy do „prawdziwie spekulatywnej czasowości”, trzeba zrozumieć, z czym musi ona sobie radzić w akcie zespalania pewnych skrajności.

Z jednej strony mamy więc model greckiej czasowości, związany z prostą obecnością o charakterze niezmiennych cyrkulacji, pozbawiony silnej transcendencji. W tak rozumianym uniwersum pogańskim nic się nie wydarza, o ile samo wydarzenie traktujemy jako moment „wyobcowania” się obecności od samej siebie, moment prawdziwej różnicy. Stać się może jedynie to, czego nie ma, ale skoro wszystko, co jest, jest obecne, to nie ma możliwości, nie ma przestrzeni, aby pojawiła się nieobecność, warunek czegoś innego niż to, co jest. A skoro nie ma ucieczki od tożsamej ze sobą obecności, to nie ma niczego nowego, nie dzieje się nic, co nie byłoby już tym samym, co jest. „Pojęcie wyzewnętrznienia nigdy nie pojawia się w Heglowskich analizach myśli greckiej” (Malabou 2005, 113), jak zauważa Malabou, a nawet więcej, niekiedy sam Hegel pisze, że w przedchrześcijańskim świecie w ogóle nie dysponowano pojęciem czasu (,w greckiej kulturze nie był obecny jeszcze czas”; Hegel 1994, 512). Jeśli w ogóle w greckim świecie możliwy był do pomyślenia czas (a Malabou rozsądnie uważa, że owszem), to był to czas teleologiczny, który wszystko, co się zdarza, podporządkowuje immanentnemu horyzontowi obecności, założonemu z góry porządkowi logosu. 
Taka czasowość zderza się w pewnym momencie dziejowym z filozofią chrześcijańska. Ta z kolei jest w zasadzie niczym innym jak teoretyczną celebracją wydarzenia, jakim było wcielenie. Ten jednostkowy, niepowtarzalny, z niczego nie wynikający i niewywodliwy z przeszłości prosty fakt, że oto stało się coś zupełnie nie z tego świata, radykalnie zmienia modalność czasu:

Wielka rewolucja w czasie spowodowana przez chrześcijaństwo jest paradoksalnym
zapoczątkowaniem nie-rekurencyjnego czasu. Czas, który odwraca bieg historii, jest
czasem, który sam nie wraca, ani się nie powtarza; to czas linearny, radykalnie
odmienny od czasu teleologicznego (Malabou 2005, 116).

Chcemy podkreślić, że pojawiające się tutaj słowo „rewolucja” nie jest przypadkowe. Czas chrześcijański, nowy czas, który sam jest warunkiem możliwości tego, co nowe, tego, co niezakorzenione w statycznej obecności, jest sam zarówno rewolucją, jak i zarzewiem każdej ewentualnej rewolucyjności jako takiej. Sam jest warunkiem swojej możliwości. $\mathrm{Na}$ tym polega paradoks jego powstania, że nie mógł się wydarzyć tak długo, jak długo nie zaistniało „wydarzenie”, ale samo to wydarzenie zaistniało jako „wydarzenie” tylko dlatego, że nie mogło się wydarzyć do tej pory, na zasadach określanych przez inną modalność czasu. Jeśli czas grecki był czasem absolutnej bierności i receptywności, to czas chrześcijański jest radykalną spontanicznością i zerwaniem, pewną niezdeterminowana przypadkowościa jako taką. Jak zauważa Malabou, Hegel do określenia tej nowej czasowości nieustannie używa pojęć „zmiany” i „,rewolucji” (por. Malabou 2005, 115).

Myślenie rewolucji to u zarania - ale tylko u jej zarania, jak się okaże - przede wszystkim myślenie czasu jako negatywności, która zgładziła czas starożytny. Jest to pewien szczątkowy i pierwotny, lecz niezwykle silny paradygmat, który nowożytność wiąże ze zmiana. Dla Hegla, ale i dla interpretującej go Malabou, to właśnie „Chrystus jest figura czystego wydarzenia, dokładnym przeciwieństwem przyzwyczajenia” (Malabou 2005, 117). I tak jak wcześniej mówiliśmy o rewolucji, która w rejestrze pojęciowym sama się nagle stwarza, tak i tutaj czas linearny, czas nadchodzącej utopii stwarza się sam: „To, że Chrystus [...] wkracza w czas, nie znaczy, że wkracza w czasowość już istniejąca. Pojęcie czasowości, w którą się angażuje, ustanawia Bóg. W rzeczy samej, on je stwarza (Malabou 2005, 120)”.

Ale to proste, niedialektyczne zestawienie czasu starożytnego i czasu nowożytnego nie jest ostatnim słowem spekulacji. Bo choć chrześcijaństwo zapoczątkowało możliwość myślenia o rewolucji w ogóle - dlatego Hegel tak chętnie posługuje się na określenie tego wydarzenia rzeczonym pojęciem (np. „To królestwo Boga, nowa religia, ma więc samo w sobie określenie negacji w stosunku do tego, co istnieje; jest to rewolucja w obrębie nauki [...]"; Hegel 2007, 297) - to konstrukcji tego pojęcia nie doprowadziło do końca. 
Rewolucyjność, radykalna zmiana jako taka pojęciowo oznacza o wiele więcej niż nagłość jednostkowego wydarzenia. Chrześcijaństwo nie myśli jeszcze rewolucji, myśli tylko inny, skrajny i przez to abstrakcyjny model czasowości. Czas chrześcijański jest niczym innym jak właśnie abstrakcyjną negatywnością, która przeciwstawia „masywnej”, substancjalnej rzeczywistości tego, co obecne (czasowi greckiemu), jedynie pustkę rozproszonych, wyalienowanych od siebie zdarzeń, w tej alienacji pozbawionych wzajemnych odniesień i ulatniających się w swojej przypadkowej, irracjonalnej beztreściowości.

Jeśli modalność czasu starożytnego odpowiada pewnej konserwatywnej, pogańskiej w istocie utopii à la de Maistre, gdzie nic się nie dzieje, bowiem wszystko zostało raz na zawsze ustalone, to modalność czasu nowożytnego odpowiada utopii mesjańskiej, w ramach której fetyszyzuje się czyste zerwanie, nie bacząc na to, czy owo zerwanie nie jest li tylko abstrakcją tego, co absolutnie nowe, bez żadnej społecznej treści. Można tutaj przywołać pojęcie „destrukcyjnej plastyczności” z Ontologii praypadtości jako model takiego właśnie czystego wydarzenia - ale czy istnieje możliwość realizacji utopi owej „nowości” na płaszczyźnie dziejowej? Nie jest chyba przypadkiem, że kiedy Malabou analizuje to pojęcie, wszystkie przykłady owej plastyczności bezproduktywnego „nie”, „nie” eksplozywnego, mają charakter indywidualny, psychologiczny bądź biologiczny. Czysta nowość, w której to, co minione, nie jest w stanie się rozpoznać - jak w przypadku przebudzenia Gregora Samsy (Por. Malabou 2017, 29) - nie może mieć raczej charakteru społecznej czy choćby intersubiektywnej zmiany, skoro kryterium „eksplozywności” zależy tutaj od recepcji samego indywidualnego podmiotu; od tego, czy rzeczywiście rozpoznaje on w nowej formie cokolwiek $\mathrm{z}$ tego, kim był do tej pory. Jak takie kryterium osiagnać w przypadku podmiotów zbiorowych? Przykładem, jakim można się posłużyć przy eksplikacji destruktywnej plastyczności w polu refleksji społecznej, jest kolonizacja widziana z perspektywy autochtonów - wydarzenie zmieniające całość relacji międzyludzkich, które w żaden sposób nie wynikało z intensywności czy treści owych relacji - albo jakaś katastrofa, wprowadzająca na miejsce porządku społecznego „nowe barbarzyństwo” (por. Lukács 1988, 508), trudno jednak takie wydarzenia określać mianem wychylonej w przyszłość rewolucji społecznej.

Ale Hegel, jak wiadomo, znosi w Wiedzy Absolutnej czasowość w ogóle. Sens tego zniesienia wyznacza paradygmat nowoczesnego rozumienia rewolucji i zmiany. Jest to też ten wątek Heglowskiej dialektyki, który dla Malabou wyznacza możliwość przyszłości Hegla tego, że istnieje przyszłość u samego Hegla, i tego, że jego filozofia ma przed sobą przyszłość.

Wychodząc poza skrajne i podwójnie utopijne rozumienie czasowości pogańskiej i chrześcijańskiej, Malabou, wbrew interpretacjom Heideggera (por. Heidegger 2005, 542546), na swój sposób przedstawia ów wątek z końcówki Fenomenologii ducha. Czytamy tam: 
„Czas to pojęcie samo, czyli czyste Ja, które istnieje i przedstawia się świadomości jako pusty ogląd; dlatego duch z konieczności przejawia się w czasie i przejawia się w nim dopóty, dopóki nie ujmie swego czystego pojęcia, czyli dopóki nie przekreśli czasu" (Hegel 2002, 510). Zdaniem Malabou w żadnym razie nie mamy tutaj prostego powrotu do teleologicznej bezczasowości o pogańskiej proweniencji. Taka wulgarna interpretacja zupełnie rozmija się bowiem z samą istotą Heglowskiej narracji, w której kluczowym pojęciem jest wszak plastyczne zniesienie, które tyleż niszczy, co nadaje nową formę ${ }^{3}$. A Heglowi chodzi właśnie o to, aby w tych postnowożytnych czasach nadać samemu czasowi formę, która wyjdzie poza jałową opozycje greckiej substancji i jednostkowej podmiotowości chrześcijan, w ramach której zarówno jedni i drudzy wikłaja się w swoje pozornie niemożliwe do uzgodnienia temporalizacje. Czy Hegel miał na uwadze właśnie to, że jego czasy są czasami postrewolucyjnymi i dlatego domagaja się koncepcji czasowości rzetelniejszej z punktu widzenia dialektyki, odpowiadającej czasowi, w którym żył? Czy może to wydarzenie rewolucji determinujące ducha czasu bezwiednie zmusiło Hegla do przeformułowania chrześcijańskiego czasu linearnego jako czasu, który się już wyczerpał? Malabou nie rozstrzyga tej kwestii, niemniej jednak jedno pozostaje dla niej pewne:

\begin{abstract}
Jest jasnym, że w rozdziale o wiedzy absolutnej czas, o którym mówi Hegel, to czas alienacji; a nawet dokładniej, ten czas to samo Entäußerung. Jako temporalna forma analizowany tam czas reprezentuje konkretną epokę przełożenia tego, co duchowe, w to, co zmysłowe. To moment, w którym pojęcie nadaje sobie kształt czegoś istniejącego, stając się tym samym obiektem poznania zmysłowego, chwilowa obecnością fenomenalna. W rozdziale o wiedzy absolutnej Hegel nie rozważa czasu w ogóle, ale czas liniowy [...] (Malabou 2005, 128).
\end{abstract}

Czas oparty na serii momentów, serii wyzewnętrznień, liniowy czas chrześcijaństwa dobiegł końca, ale to nie znaczy, że zakończyła się historia. W pewnym sensie historia właściwie dopiero teraz się rozpoczyna, ponieważ dopiero teraz dysponujemy właściwym spekulatywnym - pojęciem przyszłości. Nie jest to pojęcie wiążące to, co nadchodzi, w immanentyzmie teleologii ani w chwilowości mesjanizmu. Obydwie te modalności czasu wyczerpały swoje możliwości opisywania/regulowania dziejów świata. W 1807 roku, 18 lat po Wielkiej Rewolucji, filozofia ma już narzędzia, aby oddać sprawiedliwość nowemu czasowi, który się wydarzył, czasowi, który nie jest już ani substancja, ani podmiotem, ale sam jest prawdziwą rewolucja, ponieważ ,jest tym, czym nie jest. Zmienia i na mocy swego pojęcia podatny jest na rewolucje. Jego punktem zwrotnym jest negatywnośc’” (Malabou 2005, 115).

3 W tym kontekście można dodać, że mimo wszystko sam Heidegger tę dwuznaczność zniesienia - (która tak dokładnie pokrywa się z dwuznacznością plastyczności) to, że jest zarówno niszczeniem, jak i tworzeniem świetnie opisał i precyzyjnie umiejscowił w samym sercu Heglowskiego systemu (por. Heidegger 1997). 
W kolejnym fragmencie Malabou podsumowuje:

Hegel ujmuje dwie temporalne modalności: teleologię, odnoszącą się do greckiej formy „prze-widywania”, oraz alienację, nawiązująca do współczesnej formy „przewidywania”. Połączenie tych dwóch czasów wyznacza przyszłość istot, które nie maja już czasu przed sobą, które przeżywają teleologię rozbita, gdyż wypełniona. Taka przyszłość jest zarówno piękna, jak i przerażająca. Piękna, ponieważ wszystko wciąż może się wydarzyć. Przerażająca, ponieważ wszystko się już wydarzyło (Malabou 2005, 192).

Czas Hegla to czas zapośredniczający teleologię i mesjanizm, nie rozpadający się na te skrajne momenty, ale w plastycznych operacjach przekształceń wiążący je ze sobą w jedność. Taki czas pozostawia wszystko takim, jakie było, ale jednocześnie nieustannie krzewi w swym przebiegu nowość. Zrywa z przeszłością tylko po to, aby nieustannie ja zachowywać. Taki czas nie jest abstrakcyjną pustką trwania ani równie abstrakcyjną zawieruchą rewolucyjnego terroru, ale żywą wzajemnością dwóch modalności czasu, które stoją za owymi abstrakcjami.

Czas rewolucji to czas, który sam ma formę swojej treści. Jest nagły i jednocześnie monotonny. Teza Malabou wydaje się więc prosta - tak jak czas starożytny był czasem substancji, tak czas nowożytny był czasem alienacji, natomiast czas obecny to czas rewolucyjnego zniesienia alienacji, które nie jest powrotem do substancjalnej, niezmiennej przeszłości, ale dynamicznym procesem stwarzania i niszczenia, zrywania i wiązania historii. Takie właśnie rozumienie czasu determinuje filozoficzne próby ujęcia i zrozumienia tego, czym jest sama zmienność jako taka, a zatem czym jest rewolucja, która musi operować w czasie opisanym przez Hegla jako plastyczność i spekulatywność. Stąd też:

\footnotetext{
Przyszłość nie jest czymś absolutnie niewidzialnym, podmiotem absolutnej transcendencji, wzbraniającym się przed wszelką antycypacja, przed wiedza, przed mową. Nie jest też czymś absolutnie widzialnym, obiektem jasnej i absolutnej przewidywalności. Frustruje każdą antycypację poprzez swoją gwałtowność, swoją moc zaskakiwania (Malabou 2005, 184).
}

Ten trudny do wytrzymania splot sprzeczności, ta frustracja związana ze spontaniczną nagłością i spolegliwym trwaniem powoduje, że myślenie rewolucji w kontekście plastycznego czasu - a, jak się zdaje, dla Hegla i Malabou nie ma możliwości rzetelnie myśleć rewolucji inaczej niż w tym właśnie kontekście - nieustannie popada w skrajności, które plastyczność chce ze sobą zapośredniczać w jedności własnego pojęcia. Jak pogodzić te dwie tendencje, jak myśleć zmianę, aby zarazem była zmianą, a jednocześnie nie popadała w nierealność 
utopizmu? Widzieliśmy te trudności, czy też ten splot obecny w pojęciu rewolucji, na przykładzie de Tocqueville’a. Wydaje się jednak, że nie było myśliciela - możliwe, że całych dziejach filozofii - dla którego problem ten był tak istotny, jak dla Györgya Lukácsa.

\title{
3. Lukács
}

Rewolucja ma strukturę idei spekulatywnej, jest plastyczna, to znaczy w tej samej mierze jest aktywnością nadawania form, co biernością ich przechowywania. W rewolucję (tak jak i w samą plastyczność - por. Malabou 2010, 23) wpisany jest więc moment melancholii, która sama jest dwuznaczna; jest pogrążona w niecierpliwości tego, co przyszłe, ale zarazem ciagnie za sobą utracona przeszłość, jak kometa ogon. W swojej książce o rewolucji francuskiej i niemieckim idealizmie Rebecca Comay zauważa, że rewolucyjna przemoc jest związana właśnie z nieprzepracowaniem (niezapośredniczeniem) tej utraty: „Wszystko, co nastapiło później [tj. terror rewolucji - przyp. MAS] można przypisać oświeceniowemu żalowi za utraconym obiektem. [...] Absolutna wolność jest terrorem. To nieskończona melancholia podmiotu, który nie zna niczego innego poza nim samym” (Comay 2011, 67-68).

Czy jednak ten melancholijny charakter rewolucji dotyczy każdego przewrotu? Co z rewolucjami, które zupełnie pozbawione sympatii do historycznego status quo proklamuja całkowite zerwanie z dotychczasowym urządzeniem świata i najbardziej radykalne przeobrażenie zastanego, znienawidzonego porządku? Jeśli mieszczańska rewolucja francuska rzeczywiście była jedynie konwulsyjnym potwierdzeniem najistotniejszych tendencji oświeconego ancien régime’u, to co z rewolucją socjalistyczną?

Lukács z okresu Historii $i$ śniadomości klasowej nie ma wątpliwości. W polemicznym wobec Róży Luksemburg artykule pisze:

\begin{abstract}
$\mathrm{Na}$ tym właśnie polega najgłębsza różnica między rewolucja burżuazyjną a proletariacka. Istota rewolucji burżuazyjnych [...] polega ze społecznego punktu widzenia na tym, że w społeczeństwie, którego feudalno-absolutystyczna struktura jest nadzwyczaj głęboko podminowana przez silnie rozwinięty już kapitalizm, wyciagaja one $[\ldots]$ konsekwencje tego rozwoju społeczno-ekonomicznego, jaki w przeważającym stopniu już się dokonał. Prawdziwie rewolucyjnym elementem jest tu jednak ekonomiczne przeobrażenie feudalnego porządku produkcyjnego w kapitalistyczny, tak, że teoretycznie byłoby całkiem możliwe do pomyślenia, iż ten proces w całości odbywa się bez rewolucji burżuazyjnej [...] (Lukács 1988, 509).
\end{abstract}

W tym sensie Lukács zgadza się z de Tocqueville’em („Gdyby się nie dokonała [rewolucja przyp. MAS], stary gmach społeczny rozleciałby się wszędzie i bez niej [...]”; de Tocqueville 
2005, 56; por. też Lukács 1988, 473). Dotychczasowe rewolucje są więc ze swojej istoty jedynie logiczną konsekwencja degeneracji starego systemu, wynikają wprost z niego, a ich przewrotowy charakter powiązany jest jedynie z szybkością i gwałtownościa, a nie z jakościową zmiana. W zasadzie mogłoby ich nie być, historia mogłaby się obyć bez terroru i gilotyny. Lukács sugeruje więc, że rewolucja burżuazyjna nie niesie w sobie przyszłości, a jedynie rozwija to, co dane, natomiast rewolucja proletariacka, jakkolwiek uwzględnia dotychczasowy rozwój, to jednak wprowadza pewien nowy, zupełnie niezdeterminowany przeszłością moment:

\begin{abstract}
Oczywiście: nawet rewolucja proletariacka byłaby nie do pomyślenia, gdyby jej ekonomiczne przesłanki i warunki wstępne nie zostały już w łonie społeczeństwa kapitalistycznego wytworzone przez rozwój kapitalistycznej produkcji. Jednak ogromna różnica, jaka zachodzi między tymi dwoma typami rozwoju, polega na tym, że kapitalizm jako sposób gospodarowania rozwinął się już w łonie feudalizmu, rozsadzając go od wewnątrz. Byłoby natomiast utopijną fantazją wyobrażać sobie, że w łonie kapitalizmu mogłoby $\mathrm{w}$ sensie tendencji ku socjalizmowi powstać coś więcej niż z jednej strony obiektywno-ekonomiczne przesłanki możliwości tegoż [...], z drugiej zaś - rozwinięcie się proletariatu jako klasy (Lukács 1988, 509-510).
\end{abstract}

Cały czas jednak pozostajemy w paradygmacie myślenia o rewolucji jako o plastycznym wydarzeniu, łączącym wychylenia ku przeszłości i ku przyszłości w jednym procesie zmiany. Pozostawiony ze swymi autodestruktywnymi, immanentnymi tendencjami kapitalizm, w odróżnieniu od feudalizmu, nie przemieni się w „królestwo wolności” autonomicznie, na zasadzie „spiżowych praw” czy teoretycznie wykoncypowanych „logicznych konieczności” (jak chcieliby choćby ideolodzy II Międzynarodówki), a raczej - zgodnie z przywoływana wyżej ideą „destruktywnej plastyczności” - przemieni się w przywoływane już „nowe barbarzyństwo” (por. Lukács 1988, 508), stan ogólnej aspołeczności. Dlatego potrzebna jest pewna nowa siła - świadomość klasowa proletariatu - której zaistnienie jest tożsame ze zrewolucjonizowaniem dotychczasowych stosunków społecznych. Ale samo to wydarzenie rewolucyjne (w tym przypadku zaistnienie pewnej samoświadomej klasy) musi uwzględniać konkretny kontekst przeszłości, z którą się mierzy, brać pod uwage zależność od niego, aby nie popaść w jałowy utopizm.

Rewolucja jest więc z jednej strony nowością, której samą istotą jest odrzucenie determinantów przeszłości, z drugiej strony, choćby ze względów „taktycznych”, ciągle musi brać pod uwagę to „przeszłościowe” uwarunkowanie. Najbardziej dobitnym wyrazem owego spekulatywnego charakteru właściwej rewolucji jest Lukácsowska idea procesu jako skoku i skoku jako długotrwałego procesu. W eseju o „funkcji materializmu historycznego” czytamy: 
[...] w rewolucyjnym punkcie zwrotnym [trzeba - przyp. MAS] praktycznie brać na serio kategorię tego, co radykalnie nowe, przewrotu w strukturze ekonomicznej, zmieniającego kierunek procesu, a więc kategorię skoku [...]. [...] skok, o którym mowa, jest raczej długotrwałym i mozolnym procesem [...]. Skok wydaje się więc bez reszty zanikać w procesie (Lukács 1988, 462-463).

To jest właśnie precyzyjne określenie, na czym polegać by miało plastyczne rozumienie rewolucji. Nie niwelacja przeszłości, ale jej przeformułowanie, z którego - na poły emergentnie, na poły dialektycznie - wynika nowa przyszłość. Cięcie, które nie ma charakteru punktowego, ale rozciaga się w czasie, niekiedy na tak długo, że wydaje się, iż zupełnie zatraca swój skokowy charakter. Jednak tym, co wciąż gwarantuje ów skok rewolucji jest właśnie, co?

Czym jest to, co należy w pełni do przyszłości w rewolucji proletariackiej? W toku analiz Lukácsa, których nie sposób tutaj streścić, okazuje się, że żadna konkretna propozycja nie jest zadowalająca. To wszak dotychczasowe, kapitalistyczne stosunki produkcji uspołeczniły całość relacji międzyludzkich (por. Lukács 1988, 441), wytworzyły również warunki możliwości rewolucji proletariackiej, zarówno kryzys (por. Lukács 1988, 264), jak i narzędzie jego rozwiązania, proletariat (Lukács 1988, 341). Sam proletariat jednak pogrąża się w zachowawczej i antyrewolucyjnej ideologii, tracąc przewodnią, „nowatorską” rolę (por. Lukács 1988, 485-489), a partia, mająca na poziomie teoriopraktycznym gwarantować czystość ostatecznego celu (por. Lukács 1988, 561), sama wikła się w burżuazyjne, wewnętrzne wojenki, powielając w sobie struktury kapitalistycznej administracji (por. Lukács 1988, 588-589), tak więc nieustannie „[...] nawracaja tutaj antynomie stanowiska kontemplatywnego jako sprzeczność pomiędzy pragmatyzmem i utopizmem” (Lopez 2014). W tym kontekście nieustannych poszukiwań tego, co nowe, rewolucyjne, skokowe, przyszłe, a także nieustannych nie tyleż klęsk, co po prostu dialektycznych subtelności, w które wikła się Lukács, zatraca się plastyczność samej proletariackiej rewolucji, która grzęźnie w mieszczańskich sprzecznościach przeszłości, w niedialektycznym sprzęgnięciu tego, co musi zostać przekształcone, i tego, co jawi się dopiero na horyzoncie. Wielkość Lukácsa jako filozofa polega między innymi na tym, że przed tymi problemami, wytworzonymi przez same dialektyczne struktury myślowe, nie ucieka w pusty deklaratywizm, ale realnie szuka ich rozwiązania.

Wszystkie te konkretne rozwiązania napotykają tę samą trudność. Wciąż jedynie reprodukuja kwestię „przeobrażenia transcendentnego założenia celu w immanentne” (Lukács 1985, 172) na innym poziomie. Odwołuję się tutaj do wcześniejszego tekstu autora nie przez przypadek, bowiem można zaryzykować tezę, że jakkolwiek zmienia się jego stosunek do problemu i perspektywa, z jakiej się ów problem postrzega, zmienia się również 
waloryzacja rozwiązań (choćby kwestia mesjanizmu) - to samo pole teoretyczne Lukács opracował już w swych najwcześniejszych publikacjach: jak przełamać antynomie stanowiące istotę współczesnego społeczeństwa ${ }^{4}$ ?

Zatem nieustannie poszukuje on realnego zapośredniczenia, które nie rozpadałoby się w praktyce rewolucyjnej na swe skrajności w postaci utopizmu celu i oportunizmu ruchu. To jego dialektyzowanie rewolucji jest, jak się wydaje, ciagła próbą sprostania trudnej plastyczności zmiany, której to idei pozostaje wierny.

Wydaje się jednak, że to właśnie ta wierność jest poszukiwanym momentem nowości, tą przyszłością realizowaną tutaj i teraz, która gwarantuje zmianie rewolucyjnej nieutopijne wyzwolenie z jałowego, jedynie bezpośredniego zestawienia tego, co było, i tego, co nadchodzi. W jednym z fragmentów najsłynniejszego eseju z Historii i świadomości klasowej, dotyczącego urzeczowienia, czytamy:

Tylko wtedy, gdy myślenie występuje jako forma rzeczywistości, jako moment globalnego procesu, może ono dialektycznie przezwyciężyć własną zakrzepłość i przybrać charakter stawania się. Z drugiej strony stawanie się jest zarazem zapośredniczeniem między przeszłością a przyszłościa. [...] Konkretne Tu i Teraz, gdy rozpływa się w procesie, nie jest już żadną umykająca, nieuchwytna chwila, wyślizgująca się bezpośredniością, lecz jest momentem najgłębiej sięgającego i najdalej rozgałęzionego zapośredniczenia, momentem rozstrzygnięcia, momentem narodzin tego, co nowe (Lukács 1988, 409).

Tym, co realnie nowe, jest sam moment, w którym to, co nowe, może zaistnieć. Ten moment nowości jest sam w sobie czymś nowym. Myślowe ujęcie teraźniejszości jako procesu, w którym rozpływają się abstrakcyjne przeszłość i przyszłość, zrozumienie tego powiązania dwóch modalności czasu ma charakter rewolucyjny. Skok jako proces jest skokiem właśnie dlatego, że wprowadza do tej pory zupełnie niespotykana, choć w całości oparta na dotychczasowym „materiale”, relację między skrajnościami. Tym, co nowe w rewolucji, nie jest deklarowany przez nią obraz przyszłości, ani nawet jej praca nad przeszłościa, ale ona sama jako plastyczny proces zapośredniczenia. To nowe pojęcie rewolucji jest tym, co w rewolucji jest nowe. Rewolucja jest przede wszystkim rewolucją samej siebie, rewolucja rewolucji.

Oczywiście, takie filozoficzne ujęcie nie może usatysfakcjonować nikogo poza teoretyzującym myślicielem, a taka „bierna” postawa mierzi Lukácsa najbardziej, będąc

4 W tym sensie Lukács na zawsze pozostał intelektualnym spadkobiercą swojej młodzieńczej formacji intelektualnej, owego - jak pisał o tym Michael Löwy - „romantycznego antykapitalizmu” (Por. Löwy 1979, 22 i dalej). 
dla niego nieustannym zagrożeniem. Ale jest to jedyne rozwiązanie, które wytrzymuje próbę metodologiczna, tzn. czyni zadość Heglowskiemu dziedzictwu spekulacji.

Wydaje się jednak, że finalnie Lukács musi pogodzić się z tym, iż sama idea rewolucji społecznej jest ze swej istoty czymś nazbyt dialektycznym, nazbyt „oportunistycznym”, aby mogła sprostać ukrytemu „mesjanizmowi” jego własnych oczekiwań. To pogodzenie się jest dla niego jednoznaczne $z$ rezygnacja $z$ idealistycznych mrzonek o radykalnej zmianie społecznej. Tak jakby sama nowość owej dialektycznej idei - idei dialektyki jako takiej - nie mogła swoją waga przewyższyć utraty patosu utopijnej „wydarzeniowości” (jak pisał swego czasu: „świadome zwolnienie tempa realizacji [socjalizmu] wpływa zwrotnie na patos samej woli”; Lukács 1985, 167). Jednocześnie rozczarowanie co do idei rewolucji zwrotnie wpłynęło u Lukácsa na jego ocenę rewolucji burżuazyjnych, które teraz okazują się równie plastyczne - na dobre i złe - co rewolucje antykapitalistyczne. Ich antynomie są antynomiami samej rewolucyjności jako takiej, od których nie jest wolna również rewolucja socjalistyczna, a ich ewentualna nie-plastyczność może być ujęta jedynie w horyzoncie plastyczności, w której już zawsze operuja jako jej modus prywatywny.

Uznanie, że wpisane w plastyczność strukturalne zrównanie rewolucji burżuazyjnej i proletariackiej jest czymś, przed czym dialektyka nie jest w stanie się obronić, radykalnie zmieniło stanowisko Lukácsa. W dalece późniejszym dziele Lukács, świadom już w pełni uwikłań rewolucji w plastyczność (czyli tutaj - zbyt głębokiego uwikłania każdej rewolucji w przeszłość), pisze więc:

\footnotetext{
[...] rozwój ludzkiego gatunku jest procesem rozwijania się czegoś już realnie istniejacego, a nie skokiem z jednej formy do drugiej; skok nastapił raczej w momencie uczłowieczenia się ludzkości, odtąd zaś, pomimo cofnięć, rewolucyjnych i kontrrewolucyjnych wstrząsów, mamy tu do czynienia w sensie ściśle ontologicznym z postępującym wciąż naprzód procesem ewolucyjnym (Lukács 1984, 254).
}

W polu społecznym prawdziwie zmieniająca oblicze świata „rewolucja” nie ma już możliwości, aby zaistnieć, bez względu na intensywność i radykalność naszego praktycznego zaangażowania w generowanie zmiany. Jest tylko ciagłość procesu ewolucyjnego, który przybiera bardziej bądź mniej gwałtowne formy. Oczywiście istnieje jeszcze skok jako proces - Lukács wciąż jest zbyt dialektyczny, aby rezygnować z tego plastycznego ujęcia zmiany ale oddelegowany jest on teraz do rozważań dotyczących antropogenezy; to praca jako fenomen biologiczno-kulturowy jest takim „skokiem z bytu organicznego do społecznego, a zarazem długotrwałym procesem trwającym tysiące lat” (Lukács 1984, 71).

Ale idea plastycznej rewolucji pozostaje. Można powiedzieć, podtrzymując patos innego rodzaju niż „chrześcijański, arcychrześcijański” patos „królestwa wolności”, że żyjemy wciąż w czasach owej poheglowskiej plastyczności. A ta jest zarówno nieustannym 
rewolucjonizowaniem modalności czasu, jak i rewolucjonizowaniem samej siebie jako syntetycznego procesu zapośredniczania owej modalności. Zniesienie dotyczy również samego procesu znoszenia, plastyczność sama jest plastyczna i nieustannie się odnawia, pozostając taką samą. To dlatego - i może przede wszystkim dlatego - Malabou tak mocno podkreśla przyszłościowy charakter plastyczności i dialektyki. Skoro, jak pisze, „[...] plastyczność Aufhebung albo dialektycznego zniesienia prowadzi do jego własnego zniesienia, zrzeczenia się siebie i opuszczenia siebie" (Malabou 2010, 33), to finalnym słowem filozofii plastyczności nie jest jedynie repetycja otwartej struktury. Sama ta otwartość ewokuje i to jest jej przyszłościowy aspekt, niemożliwy do wyrugowania, tak jak i nie jest możliwe zatrzymanie dialektycznego procesu - inną historię:

Wierzę, że filozofii Hegla nie można zrozumieć bez dostrzeżenia tego fantastycznego wymiaru absolutu: obrazu historii, który powstaje w momencie, kiedy historia dobiega końca, obrazu [...] plastycznego systemu, giętkiej formy zdolnej przyjąć cokolwiek nadejdzie, włączając w to, być może, inną historię (Malabou 2010, 34).

Plastyczność nie jest obietnica innej historii ani oczekiwaniem na nią, ale jest - tylko i aż na nia gotowa. 


\section{Wykaz literatury}

Barut, Andrzej. 2008. Tradycja i rewolucja. Konserwatyzm immanentny Josepha de Maistre'a. Wrocław: Wydawnictwo Uniwersytetu Wrocławskiego.

Comay, Rebecca. 2011. Mourning Sickness. Hegel and the French Revolution. Stanford: Stanford University Press.

Hegel, Georg Wilhelm Friedrich. 2002. Fenomenologia ducha. Tłum. Światosław Florian Nowicki. Warszawa: PWN.

Hegel, Georg Wilhelm Friedrich. 1994, Wykłady z bistorii filozofii. Tom 1. Tłum. Światosław Florian Nowicki. Warszawa: PWN.

Hegel, Georg Wilhelm Friedrich. 2007. Wykłady z filozofii religii. Tom 2. Tłum. Światosław Florian Nowicki. Warszawa: PWN.

Heidegger, Martin. 2005. Bycie i czas. Tłum. Bogdan Baran. Warszawa: PWN.

Heidegger, Martin. 1997. Heglowskie pojęcie doświadczenia. Tłum. Robert Marszałek. W Martin Heidegger. Drogi lasu. Warszawa: Aletheia.

Hobsbawm, Eric, 2013. Wiek rewolucji 1789-1848. Tłum. Katarzyna Gawlicz i Marcin Stranawski. Warszawa: Wydawnictwo Krytyki Politycznej.

Martinon, Jean-Paul. 2007. On Futurity. Malabou, Nancy, Derrida. London: Palgrave MacMillan.

Kuź, Michał. 2016. $\quad$ Alexis de Tocqueville's Theory of Democracy and Revolutions. Warszawa: Oficyna Wydawnicza Uczelni Łazarskiego.

Lopez, Daniel. 2014. „Georg Lukács’s Theory of Revolution”. Marxist Left Review 8. http://marxistleftreview.org/index.php/no8-winter-2014/113-georg-lukacss-theory-ofrevolution

Löwy, Michael. 1979. Georg Lukács - From Romanticism to Bolshevism. Tłum. Patrick Camiller. London: New Left Books.

Lukács, György. 1988. Historia i świadomość klasowa. Tłum. Marek J. Siemek. Warszawa: PWN. Lukács, György. 1984. Wprowadzenie do ontologii bytu społecznego. Tom 2/1. Tłum. Kazimierz Ślęczka. Warszawa: PWN.

Lukács, György. 1985. „Bolszewizm jako problem moralny”. Tłum. Kazimierz Ślęczka. W Bogusław Jasiński. Lukács. Warszawa: Wiedza Powszechna.

Lukács, György. 1985. „Taktyka i etyka”. Tłum. Kazimierz Ślęczka. W Bogusław Jasiński. Lukács. Warszawa: Wiedza Powszechna.

Maistre de, Joseph. 2011. Wieczory petersburskie. O doczesnym panowaniu opatržności. Tłum. Marta Bucholc, Warszawa: Wydawnictwa Uniwersytetu Warszawskiego.

Malabou, Catherine. 2005. The Future of Hegel. Plasticity, Temporality and Dialectics. Tłum. Lisabeth During. London-New York: Routledge.

Malabou, Catherine. 2010. Plasticity at the Dusk of Writing. Tłum. Carolyn Shread. New York: Columbia Univeristy Press.

Malabou, Catherine. 2017. Ontologia prazypadłości. Esej o plastyczności destrukcyjnej. Tłum. Piotr Skalski. Warszawa: Fundacja Augusta hr. Cieszkowskiego.

Tocqueville de, Alexis. 1987. Wspomnienia. Tłum. Aleksander Wit Labuda. Wrocław: Zakład Narodowy im. Ossolińskich.

Tocqueville de, Alexis. 2005. Dawny ustrój i rewolucja. Tłum. Hanna Szumańska-Grossowa. Warszawa: Aletheia. 
Maciej Adam Sosnowski - doktor filozofii, adiunkt w IFiS PAN. Interesuje się dialektyka.

\section{DANE ADRESOWE:}

Polska Akademia Nauk

ul. Nowy Świat 72

00-730 Warszawa

EMAIL: msosnowski@ifispan.waw.pl

CYTOWANIE: Sosnowski, Maciej Adam. 2018. „Plastyczność i rewolucja. De Tocqueville, Malabou, Lukács.“ Praktyka Teoretyczna 2(28): 85-104.

DOI: $10.14746 /$ prt.2018.2.4

\section{AUTHOR: Maciej Adam Sosnowski}

TITLE: Plasticity and Revolution. De Tocqueville, Malabou, Lukács.

ABSTRACT: The dialectical concept of revolution emphasizes its dual character. Both in the conservative (de Tocqueville) and socialist (Lukács) versions, the revolution is a testimony to historical continuity and at the same time its violent rupture. The purpose of this essay is to capture this ambiguous phenomenon using Catharine Malabou's concept of plasticity. Plasticity, as a contemporary, post-deconstructive formula of the Hegelian Aufhebung, is passive/active formation, destruction of form and its preservation at the same time. Its essence is the same as the essence of revolution, both in the writings of de Tocqueville and Lukács. However, such ambiguity of the revolution can be interpreted as an expression of its defeat. Its entanglement in the past condemns it to unproductive opportunism, its connection with the future - to empty messianism, and the search for mediation between these extremes seems to be endless. And if postmodernity is troubled by this fiasco, then at least one aspect of the idea of revolution triumphs - a certain way of thinking about it, speculation or dialectics as such.

KEYWORDS: plasticity, revolution, dialectics, temporality, Hegel, Malabou. 